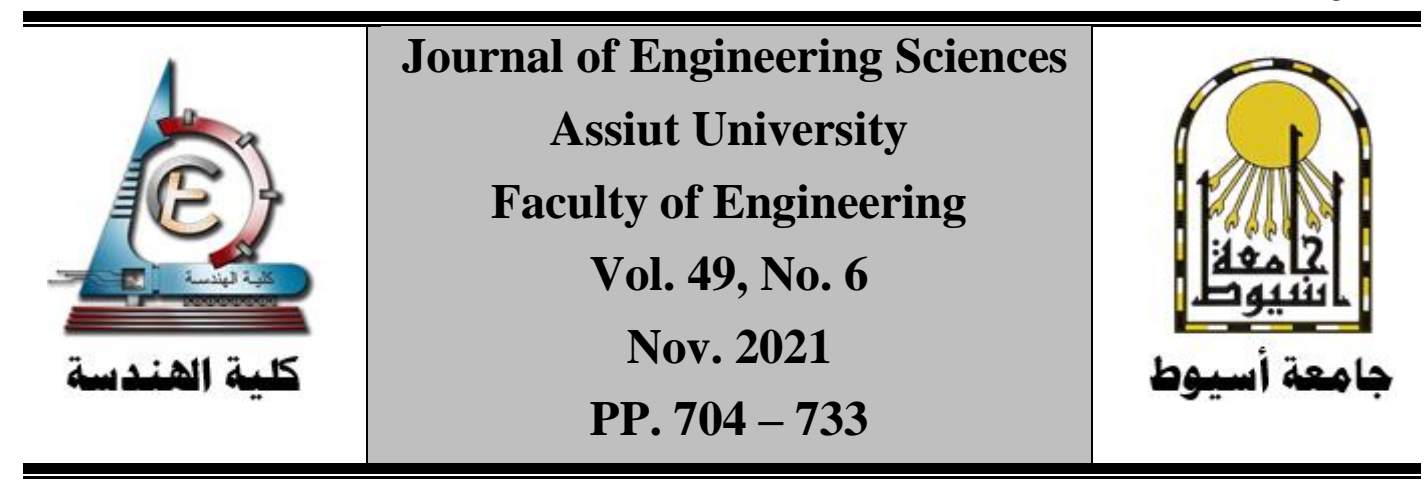

\title{
TYPES OF WORKS IN CONSTRUCTION PROJECTS IN TERMS OF EFFECTIVENESS WHEN APPLYING VALUE ENGINEERING IN SAUDI ARABIA
}

\author{
Yasser M. R. Aboelmagd ${ }^{1,2}$ and Wael F. M. Mobarak ${ }^{1,2}$ \\ ${ }^{I}$ Civil Engineering Department, College of Engineering, University of Business \& \\ Technology (UBT), Jeddah, Saudi Arabia \\ ${ }^{2}$ Mathematical Engineering and Physics Department, Faculty of Engineering, Alexandria \\ University, Egypt.
}

Received 16 June 2021; Revised 14 August 2021; Accepted 17 August 2021

\begin{abstract}
In construction projects, reduce the cost while keeping the level of quality is an important matter, which defined as Value Engineering (VE). The main concern of Value Engineering (VE) is to search for the most effective type of works in construction projects to save project direct cost by maximizing or keeping target quality for the studied project. It is a difficult challenge to keep a balance between maximizing project quality with corresponding its minimum cost and duration at the same time. When the value-engineering process is used, each factor affecting the cost is taken into consideration all detailed studies as a specific unified factor to determine its suitable alternatives. This Paper investigates ordering the types of works in terms of effectiveness in the cost saving using the value engineering process for construction projects in Saudi Arabia. A questionnaire has been used to obtain results of only valid samples from all 205 responses, which analyzed and discussed. This study concerned with some type of works in a correlation with the four main engineering categories: construction, mechanical, electrical, and finishing work. The results indicate the difference effect of using value engineering between these major categories of construction engineering works. Finally, the importance score index applied to appraise
\end{abstract}


the influence of the tested types of works when applying VE process on the project cost. This paper also serves as a resource and guide for construction managers, contractors, and more efficient management in the construction of Saudi projects to achieve a sustainable level of cost and quality.

Keywords: Value Engineering, Affecting Factors, Alternatives Solutions, Construction Works, Construction Projects, Project Cost, Relative Importance Index and Saudi Arabia.

\section{Introduction}

Value Engineering is an effective technique known to locate and exclude unnecessary costs in product design, testing, construction, manufacturing, operations, maintenance, data, practices, and procedures. Therefore, the value can enhance by either raising the efficiency or reducing cost. It is a basic principle of value engineering that preserving the quality level of main functions and because of that value improvements carried out (Mandelbaum, 2006). There are different types used in value. One of these types is use-value where the product enabled to perform its function based on its properties. Also, cost-value is another type that is based on minimizing the cost to achieve an optimum function. Moreover, esteem-value leads to make the ownership of the product proudness. In addition, exchange-value, which make exchange purposes valuable for the product (Al-Yousefi, 2007). It has to move through six phases when beginning the value engineering process: information phase, functional analysis phase, speculative phase, assessment phase, implementation phase and presentation phase (Annappa and Panditrao, 2012). These phases of value engineering could be applied in different areas such as Engineering, Manufacturing, Purchasing, Sales, Systems and Procedures, Maintenance, Energy Conversion, Construction (AlYousefi, 2012) .

Optimizes Quality/Performance is not the only benefit of applying value engineering, but there are several ones like: Reducing total life cycle costs, simplifying, and enhancing functional reliability, minimizing waste in design and manufacturing and performance, and identifying high risks (Mandelbaum, 2006) . 
Value Engineering can be used at any stage of a project's life cycle, including construction projects. However, the sooner it is implemented, the greater the return on investment in terms of time and effort. In Saudi Arabia, there is a huge interest in minimizing wasteful practices and looking at economic factors that affecting construction projects to match Saudi Arabia's 2030 vision. This study concerned with the various factors that affecting value engineering and its applications in construction projects in Saudi Arabia.

\section{Literature Review}

Larry Miles developed a reputation for great enthusiasm for developing cost-effective operations and using unconventional problem-solving methods in the late 1940s, (Mandelbaum, 2006). The Value Engineering concept gained worldwide recognition in the late 1980s. An international organization committed to its practice and the certification of skilled professionals was established (Society of American Value Engineers International or SAVE International). In addition, billions of dollars have been saved (Mandelbaum, 2006; SAVE, 2020).

To enhance the value of something, it is important to create a way and a method of measuring to improve the value of it. From the foregoing, value can be said to be based on three main components, which are cost, quality, and functionality. Where the functionality is the goal for which the item was found. In addition, quality means the beneficiary's specifications, desires, and wishes. The cost indicates the overall cost (Total Cost or Life Cycle Cost): the consumer is always drawn by initial costs, but this cost is typically between 6 and 30 percent of the total cost of building projects (Ismail et al, 2010). A case Malaysian automotive component manufacturing company's nature of business, in 1989, was to manufacture engine metal parts, and components and transmission systems (Dell'Isola, 1997). The primary source of qualitative data was Innes and Mitchell, 1990 for the case study was semi-structured interviews. On the older site, the semi-structured interviews were performed face-to-face with specific workers from various positions and hierarchical levels. The managing director, plant manager, quality staff, manufacturing, engineering, logistics, research 
and development, accounts and human resource departments were included in the informant. The study provided an explanation of the extent of VE adoption in Malaysia, particularly in the automotive sector. Application and the number of different instruments used. Overall, the findings also showed that the organizations/industries' creativity was influenced by the number of tools used in Value engineering.

Lindgreen and Wynstra (2005) have indicated that the key processes in the value creation process are creativity and product growth. Organizations need to be efficient to generate value, and it is therefore important that organizations control their costs continuously and maintain higher quality products that meet the evolving needs and preferences of customers, (Dell'Isola, 1997).

The use of the weighted-analysis approach in the evaluation phase of the traditional VE process was found to be restricting in terms of sustainable design and construction by Joel Ochieng Wao. $(r \cdot \mid \mathrm{V})$

Many studies have been performed on the development of new tools for VE, while others have concentrated on the application aspect of VE in various engineering domains, according to Mohamed et al. (2018). Future researchers who want to stay up to date on the current state of the art of VE application in civil engineering should find the study useful (Mohamed et al, 2018) .

Jae L. (2018) proposed the implementation of a decision-making method for selecting façade materials to reduce possible defects during the design stage. The case study shows that a minimum 30 percent weighting of durability for each alternative in the decision-making process will shift the priority of material choices for building façades. The contribution was the use of a value-based decision-making approach when choosing the best façade materials for long-term sustainability.

Joel W. (2018) examined traditional VE methodology and suggested a neuro-linguistic programming (NLP) approach to enhance VE creativity in green building design and construction. The aim of the study was to redesign the traditional VE creativity phase to increase green building construction outcomes.

Jingjun et al. (2020) focused on the study of two attached tower cranes that are simultaneously involved in the same building construction and proposes an optimization algorithm to determine their optimal model combination and optimal placement position, which has achieved the 
purpose of reducing costs and improving construction efficiency. This algorithm is broken down into four sections: (1) Decide the feasible layout area based on the tower crane model, component quality, and demand point position. (2) Compare the working efficiency of various tower crane model combinations to find the best combination. (3) For each model combination, determine the best placement position. (4) Use a value engineering model to compare each scenario and choose the best solution.

Junying et al. (2019) built and tested a theoretical model to examine how various types of contractor actions (perfunctory, consummate, and opportunistic) affect engineering project value added (EPVA) and the moderating effect of contract and task complexity. The data from a survey of 290 Chinese project professionals was analyzed using the multiple regression analysis method.

Sitotaw et al. (2018) investigated a groundwater management and support system consisting of secant piles built to the minimum necessary depth for a safe excavation and a permeation grout curtain wall from the bottom of the secant piles down to the bedrock. The project team used this paper to explore the design and development of alternative SOE methods, including an in-depth look at the grouting process they chose.

By examining the relationship between value management (VM) implementation and overall project performance (OPS) in Egyptian building projects, Ahmed et al. (2021) seeks to create a value management (VM) implementation model. To evaluate the VM activities obtained from previous research, fifteen experts were interviewed. The results of the interviews were validated using exploratory factor analysis (EFA). The relevance of these VM practices was further investigated using structured questionnaires conducted by building professionals.

Al - Yousefi (2012) reported that VE started in Saudi Arabia at Military Works of the Ministry of defense and Aviation. In the beginning, VE was not accepted as a new approach, but once people touched its success. The lack of adoption is due to a lack of familiarity with the VE definition among public sector organizations and local architectural/engineering firms in the Kingdom (Assaf et al, 1996). Some publications concerned with the Value Engineering applications in Saudi Arabia, (Al - Yousefi, 2007; Khalid et al, 2015), but there is still a need to focus on the chosen types of works that are the most 
effective in reducing cost when applying VE for construction projects in the kingdom.

\section{Study Aim and Objectives}

The aim of this research is to find out what types of work influencing results of value engineering in Saudi construction projects. To achieve this aim, authors achieved that by limited objectives such as:

1) Invited a statistically representative group of professionals and experts to engage in a formal questionnaire survey. 2) The use of brainstorming was considered, and a range of cost variance factors for Saudi construction projects were identified. 3) These considerations were chosen for inclusion in the questionnaire study, which was conducted with the help of experts and representatives from local general construction firms. 4) Focus on measuring the types of works influencing the results of value engineering process, which is an important necessity to determine how efficient these processes are in improving the efficiency, functionality, reliability, benefits, and costeffectiveness of construction projects. 5) It is assumed that types of works need to be specified to achieve this aim. 6) Through a survey of construction firms, the data were analyzed and addressed using the Relative Importance Index, rating, and basic percentages to determine their impacts. 7) Finally, to deal with these factors, a conclusion and some recommendations were proposed.

\section{Research Methodology}

As shown in Figure.1, the research approach included several stages aimed at achieving the study objectives. The investigation of variables for evaluating VE output in construction projects by examining the related literature has initiated in these phases. The previous steps led to the identification of a list of types of works deemed to be with various influences the performance of VE in construction projects. The list of types of works forms the basis of the questionnaire, which aims to classify the most significant types of works influencing the output of VE in Saudi Arabia's construction projects. 


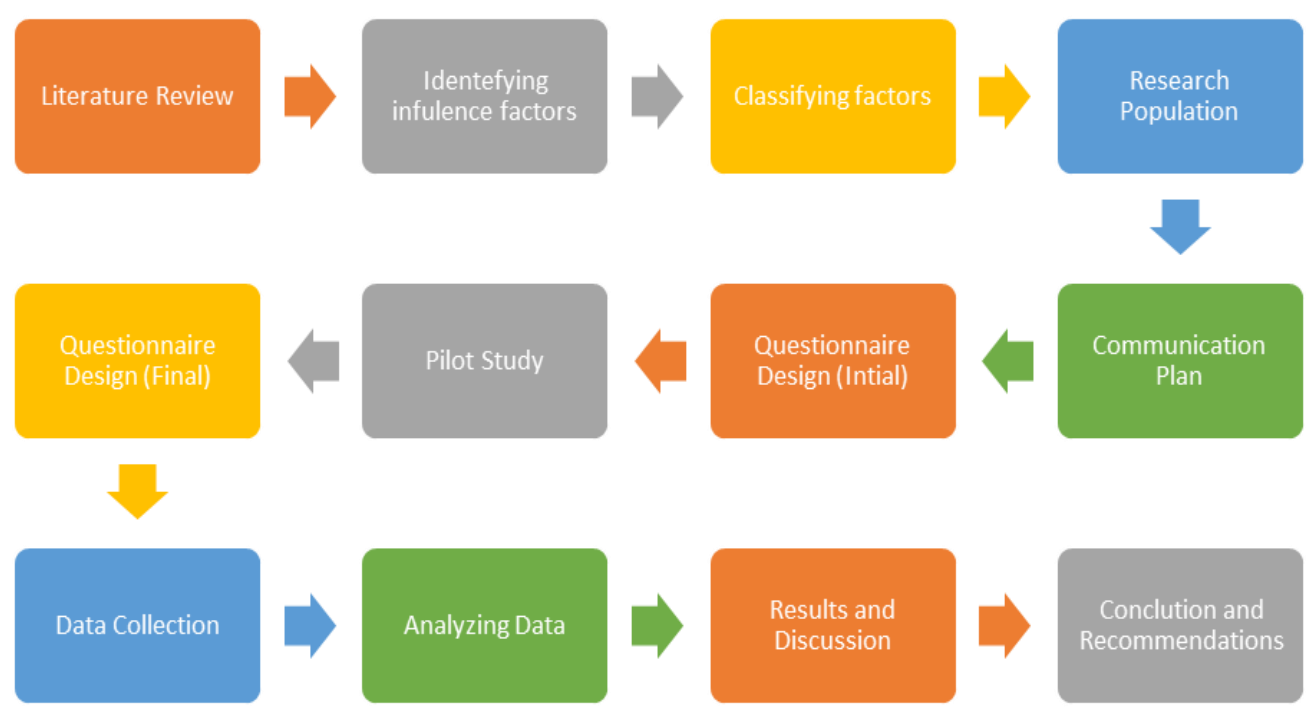

Figure.1. Research Methodology.

In this research, the target practitioners were project stockholders involved in construction projects in Saudi Arabia. Investigating the views of these practitioners would undoubtedly help to recognize the most significant types of works influencing the variation when applying VE process in Saudi Arabia, since they control in Saudi Arabia's construction industry. The research population includes engineers from organizations that own, design, consult, and contract. A communication plan was then developed to make the process of data collection simple and precise. In the end, the collected data was evaluated to obtain the results.

\section{Process Of Value Engineering}

Value Engineering is not the same as design/peer review or costcutting. Value engineering is an innovative, well-organized effort that examines a project's specifications to accomplish the most important functions at the lowest possible life cycle cost (LCC). Value and economy were enhanced through the analysis of alternative design principles, products, and approaches without compromising the client's functional and value goals through a group investigation using 
professional multi-disciplinary teams. According to Dell'Isola (1997), VE should be carried out with a very organized and coordinated job plan as early as possible before the commitment of funds to achieve the benefits of value engineering as shown in Figure.2, Sharma (2012). The gained value of applying VE in the proposal stage or conceptual design stage will be great, while the net gained value reduced in application in schematic design or design development stage. If VE is used in the stage of preparing construction documents, there will appear a conflict point where the earned value will start turned into a net loss. Where VE application in construction stage will lead to a certain net loss.

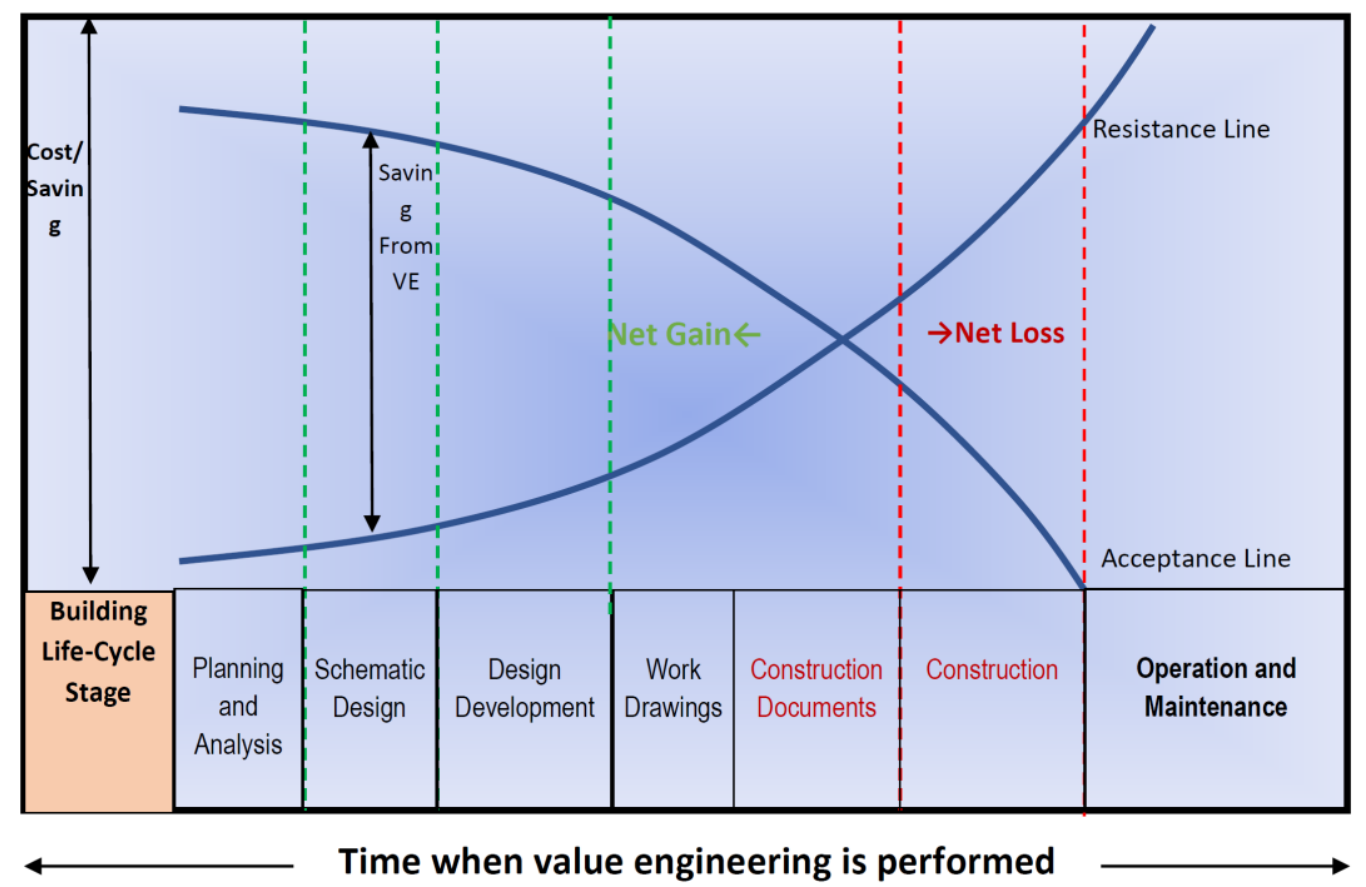

Figure.2.Potential saving from value engineering

\section{Value Engineering Methodology}

Value Methodology (VM) is an organized analysis system that uses qualified multidisciplinary teams to evaluate a project's requirements for achieving its critical functions at the lowest total cost over the life of the project (capital, service, and maintenance). 
The application of Value Methodology has evolved to cover nearly every sector of the human industry, covering a wide variety of processes and facilities, including architecture and construction. The application of Value Methodology to the design and construction of public facilities, especially construction projects, is of particular interest.

\section{Questionnaire Form and Design}

To explore the research objectives, a survey instrument developed to collect specific information. The questionnaire has specifications and characteristics of the target information. The questionnaire is to determine the more costly work in the budget of a project and how can it reduce the cost in this work.

The communication strategy was conducted through interviews and online questionnaires with the target population. Based on a list of 25 questions, the initial questionnaire was developed. Using the initial questionnaire, a pilot study was performed to verify the initial questionnaire by interviewing 10 construction management experts from the construction industry in Saudi Arabia. The final questionnaire was built based on the final list of variables and distributed to the target population. Two main sections were included in the final questionnaire. The first part included some general questions to explore details about the respondent and organization, such as roles of respondents, number of years of experience, type of organization and VE experiences, Table.1. The second part included a list of 13 questions about the factors affecting the project to reduce the cost,

Table.2. These factors classified in four main types of work. The four types of work are civil works, mechanical works, electrical works, and architectural works. The questionnaire is targeting to determine the range of each work and the effect in the total budget. In addition, the questionnaire is answering about the most effective sub-factors inside each type of work. Such that in civil work, comparing effectiveness of the two sub-factors; underground works and the skeleton works. Moreover, the questionnaire goes in depth to examine the costliest item 
inside these two sub-factors works. Furthermore, the rest 3 types of work measured with the same way.

Questionnaires are very important and highly effective ways of collecting digital data and measuring the effectiveness of applying VE. Based on their professional judgment on a given choice, the respondents were asked to rate each indicator. The outcomes of fulfilling the goals of the study can be achieved by evaluating the data obtained through the questionnaire.

Table.1.General Question

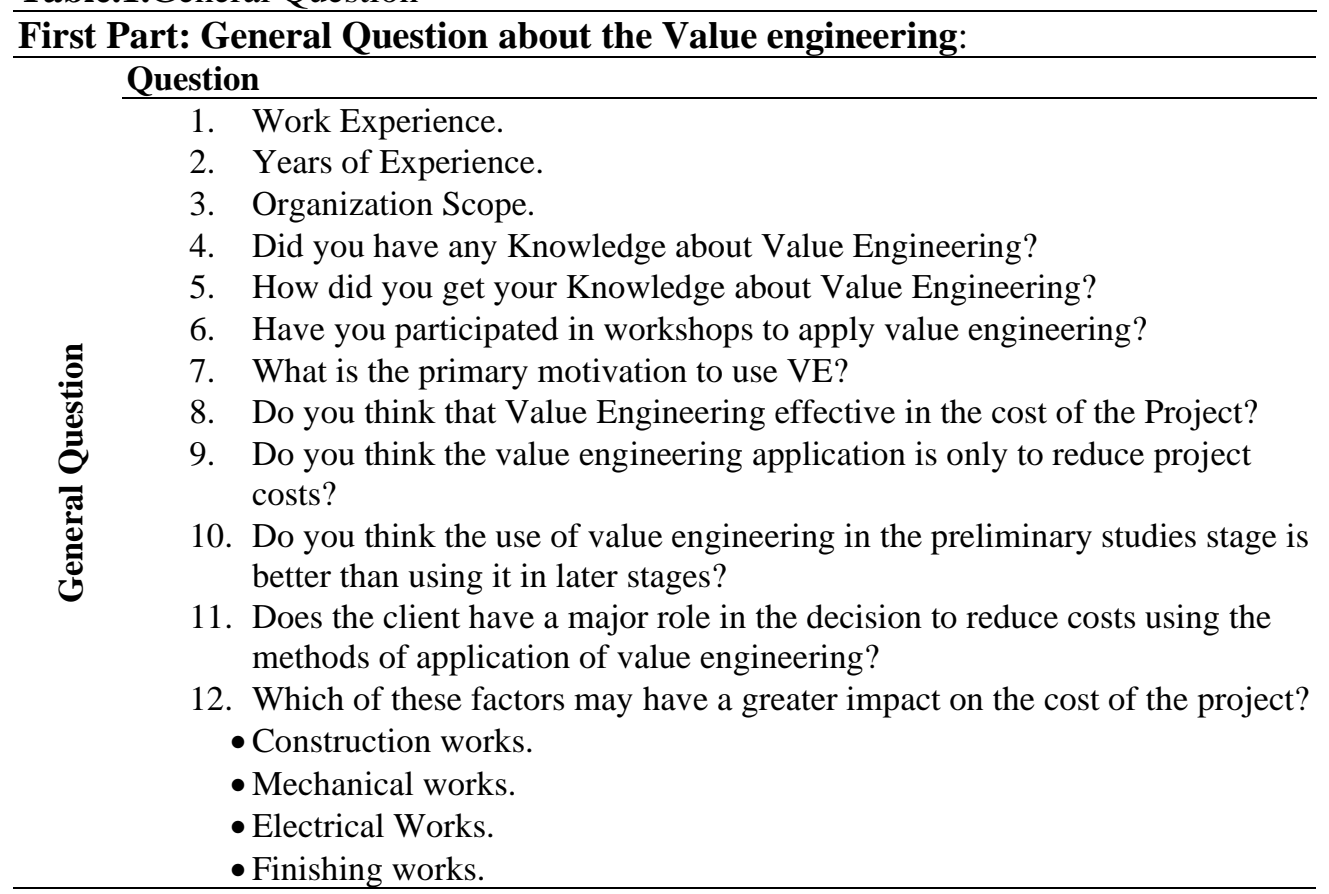

Table.2.Factors affecting construction projects.

Second Part: Factors affecting the project to reduce the cost:

\section{Question}

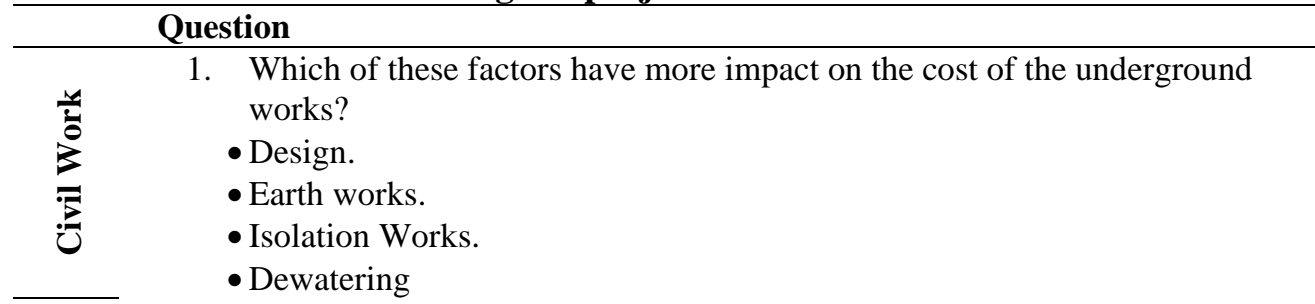


Second Part: Factors affecting the project to reduce the cost:

\section{Question}

2. Which of these factors have more impact on the cost of the Skeleton works?

- Design.

- Slabs.

- Columns.

- Brick works.

3. Which one of these factors have more impact on the cost?

- HVAC.

- Plumbing.

- Fire systems.

4. Which of these factors have more impact on the cost of the HVAC works?

- Design.

- Air condition.

- Ventilation.

5. Which of these factors have more impact on the cost of the project?

- Plumbing works:

- Design

- Internal plumbing

- External plumbing

6. Which of these factors have more impact on the cost of the Fire?

- Systems works:

- Design.

- Materials and types of piping.

- Types of valves.

7. Which one of these factors have more impact on the cost?

- Low current.

- Power.

- Lighting system.

- Fire alarm system.

8. Which of these factors have more impact on the cost of the Low Current works?

- Design.

- CCTV.

- BMS.

9. Which of these factors have more impact on the cost of the Power supply works?

- Design.

- Cables.

- Electric panel.

10. Which of these factors have more impact on the cost of the project?

- Lighting System works:

- Design.

- Types of lighting.

11. Which of these factors have more impact on the cost of the Fire?

- Alarm System works:

- Design.

- Distribution. 
Second Part: Factors affecting the project to reduce the cost:

\section{Question}

- Types of sensors.

12. Which of these factors have more impact on the cost of the exterior works?

- Facades Material.

- Windows Material.

- Floor Material.

- Doors Material.

13. Which of these factors have more impact on the cost of the interior works?

- Plaster Works.

- Paint Works.

- Isolation Works.

- Decoration Works.

\section{Data Collection}

Based on the research methodology, the most effective types of works identified from literature review will form the questionnaire. The questionnaire distributed to construction stakeholders in Saudi Arabia by emails, with the use of Google forms. Investigating the population in the field of construction engineering, depended on the general authority for statistics annual reports in Saudi Arabia, (2020). The authority stated that the average population of engineers and specialists for the last year previously to the survey is $\mathrm{N}=132,842$ persons.

Sample size $\mathrm{n}$ and error margin E are defined by, Taherdoost, 2017 and Raosoft, Eqs. (1), (2) \& (3):

$x=\frac{Z_{\text {score }}^{2}}{r(100-r)}$

$n=\frac{N \cdot x}{\left((N-1) * E^{2}+x\right)}$

$E=\sqrt{\frac{(N-n) \cdot x}{n(N-1)}}$

Where $\mathrm{N}$ is the population size, the fraction of responses is $\mathrm{r}$, and the critical value for the level of confidence is $\mathrm{Z}$-score. 
Table 3. Z-score values.

\begin{tabular}{cc}
\hline \hline Confidence level & Z-score \\
\hline $99 \%$ & 2.58 \\
$95 \%$ & 1.96 \\
$90 \%$ & 1.65 \\
$85 \%$ & 1.44 \\
$80 \%$ & 1.28 \\
\hline
\end{tabular}

The sample size $\mathrm{n}=384$ calculated with a desired confidence level of $95 \%$, margin error $\mathrm{E}=5 \%$ and fraction $\mathrm{r}=50 \%$ for the available population $\mathrm{N}$. The questionnaire distributed on 390 persons of specialists in construction field. The received data was from 205 respondents. However, 130 respondents cleared that they have knowledge about VE, but 34 of them doesn't participate in workshops to apply value engineering. So, the data collected from those doesn't participate in VE workshops (34 respondents) has excluded from results to ensure that responses are reliable. By using the available reliable data from the 96 respondents, the results will be with $95 \%$ confidence level and a margin error $10 \%$. In this study, the collected data will be analyzed to measure the most important types of works affecting the cost of construction project from the point of view of the participants.

\section{Data Analysis}

The topic of this research focuses to rank the importance and severity of the types of works affecting the results of value engineering of the projects in Saudi public and private construction projects from different parties view as Owners, consultants, contractors, and suppliers. To determine the impacts of the important types of works which severely affect the accuracy of the cost and endeavoring to suggest solutions for them, this research has a scientific interest that 
can contribute to developing the differences of the cost that could determine the anticipated cost variance for the construction project.

In this study, the considered method specifically utilizes the comparison between four engineering trades Construction, Mechanical, Electrical, and Architectural from the cost view and which one of them works most impact cost on value engineering in the project. The questionnaire divided into two parts, first part general question about the value engineering and the second part types of works affecting the project to reduce the cost. Furthermore, the questionnaires used a fivepoint ranging from ( $1=$ Do not know and 5=High) for some questions. The rank of types of works from the ones with the highest effect to others with the lowest effect depends on the highest mean. This study primarily depends on standard deviations $(\mathrm{S})$ and means ${ }^{(\bar{x})}$.

$$
\begin{aligned}
& S=\sqrt{\frac{\sum_{i=1}^{n}\left(x_{i}-\bar{x}\right)^{2}}{n-1}} \\
& \& \bar{x}=\frac{\sum x_{i}}{n} \ldots \ldots
\end{aligned}
$$

After getting the Mean value for each type of works effect, overall mean calculated for all types of works. The received back results, when it came to experience with the responses' years of experience, varied from 0 years to above 20 years. However, when it came to profession, responses mostly were site engineers.

The percentages of Responses in terms of work experience and years of experience, Figure.3.The percentage of work experience., are:

60 Site engineers represent $62.5 \%, 11$ Contract engineers represent $11.5 \%, 10$ Design Engineer represent 10.4\%, 6 Planning engineers represent $6.3 \%, 5$ Value engineers represent 5.2\%, 2 Project manager represent $2.1 \%, 1$ Quality Control represent $1.0 \%$ and 1 Academic professor represent $1.0 \%$.

The respondents work experiences are representing various categories in construction projects.

The result of the number of respondents according to the years of experience, Error! Reference source not found., was as follows: 0 to 5 years: 19 engineers represent $19.8 \%, 6$ to 10 years: 36 engineers represent $37.5 \%, 11$ to 15 years: 21 engineers represent $21.9 \%$, 16 to 
20 years: 9 engineers represent 9.4\%, and Above 20 years: 11 engineers represent $11.5 \%$.

Count of Work Experience:

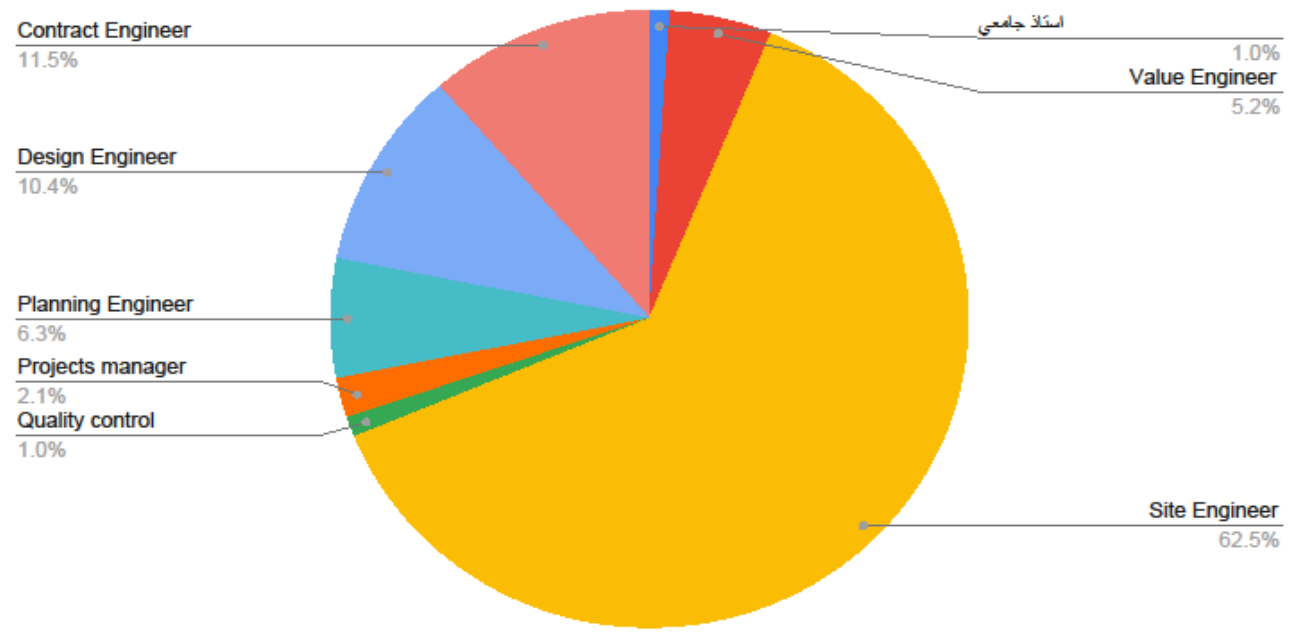

Figure.3.The percentage of work experience.

Count of Years of Experience:

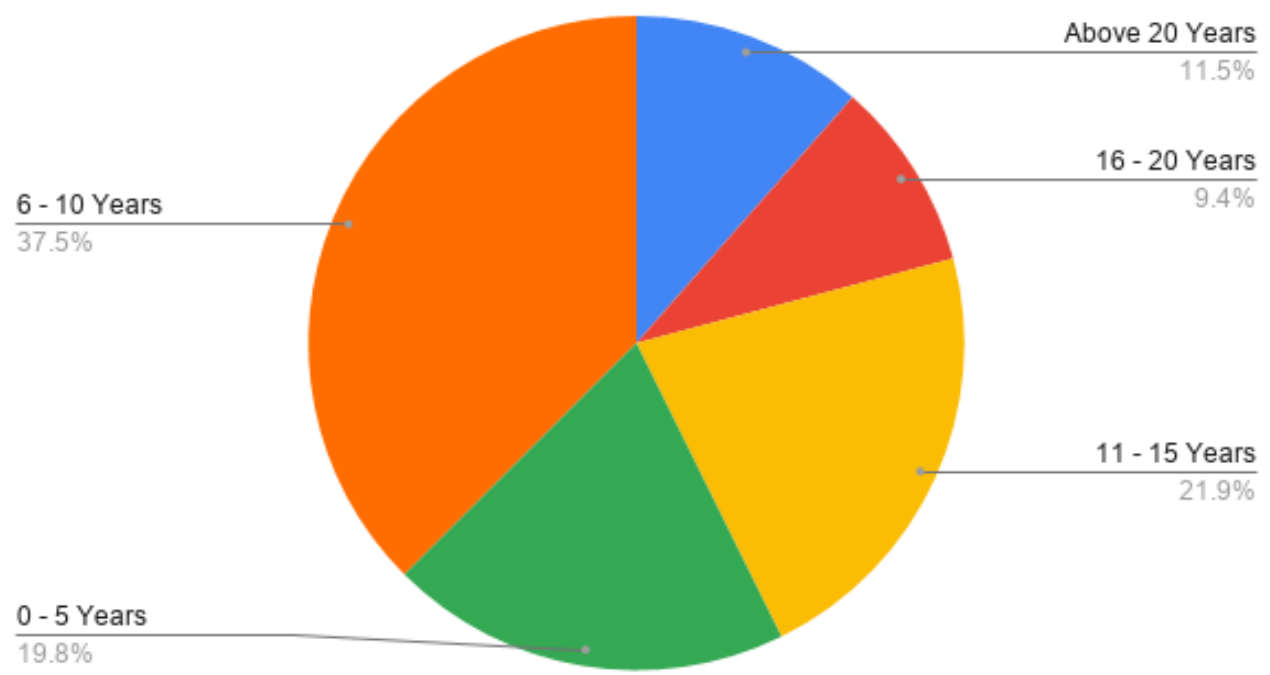

Figure.4. The Percentage of years of experience 


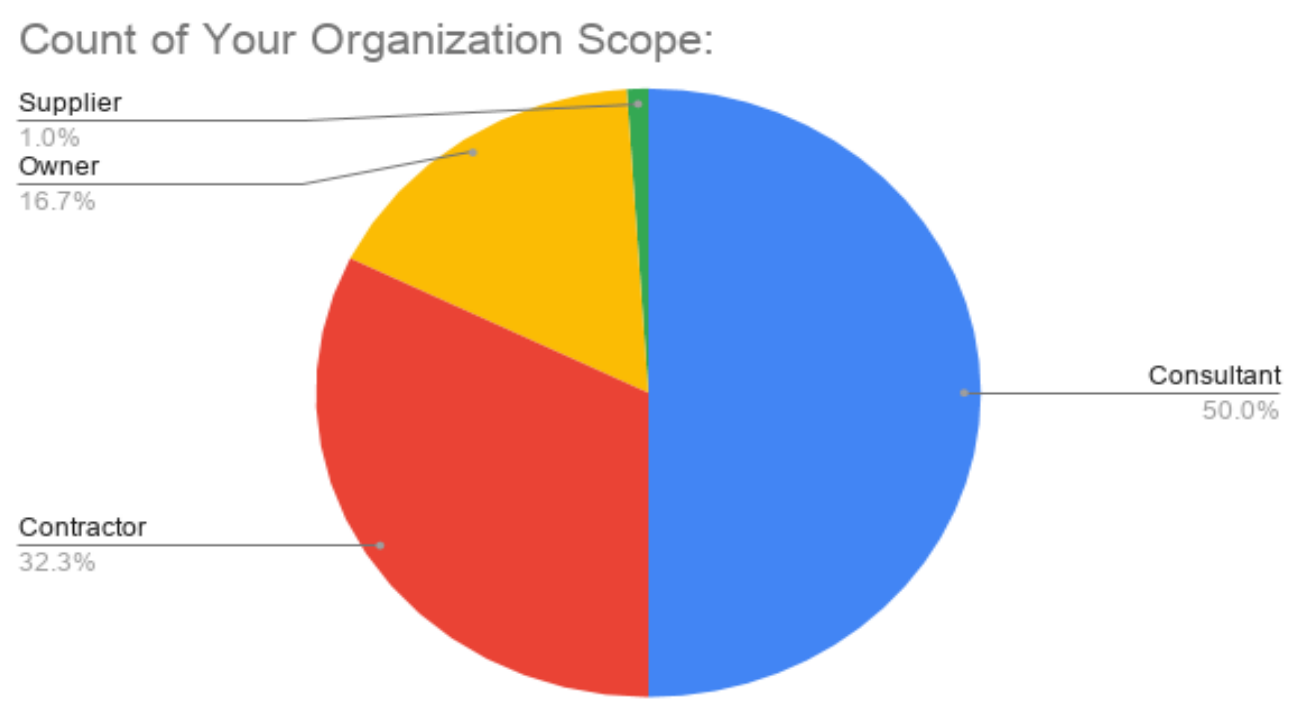

Figure.5. The Percentage of Organization scope

The sample shows that engineers less than 5 years of experience less are representing $19.8 \%$ of the sample, which indicates that $80 \%$ of the sample has an experience suitable to evaluate the case study. This high experience of respondents gives outcomes of high reliability. The result of the number of respondents according to the Organization Scope, as shown in the Error! Reference source not found., was as follows:

48 Consultants represent 50.0\%, 31 Contractors represent 32.3\%, 16 Owners represent $16.7 \%$, and 1 Suppliers represent $1.0 \%$.

\subsection{General Types of Construction Works:}

The results of the questionnaire were analyzed for each type of works as an influence factor in VE process. The statistical analysis of the questionnaire resulted data, (frequency, mean, standard deviations and percentage of influence), are shown from

Table.7 to Table.17. The range of the impact for each type of general construction works on the cost of projects is shown in the Figure.6. Where, Figure.7 shows the percentage of impact for each type of general construction works. 
Table.4. Mean and standard deviation for general types of construction works.

General Types of Works

\begin{tabular}{|c|c|c|c|c|c|c|c|c|c|c|}
\hline \multirow[b]{2}{*}{ No } & \multirow[b]{2}{*}{ Factors } & \multicolumn{5}{|c|}{ Degree of effect $\%$} & \multirow[b]{2}{*}{ Percentage $\%$} & \multirow[b]{2}{*}{ Mean } & \multirow[b]{2}{*}{$\begin{array}{l}\text { Standard } \\
\text { deviation }\end{array}$} & \multirow[b]{2}{*}{ Rank } \\
\hline & & High & Medium & Low & Neutral & $\begin{array}{l}\text { Do not } \\
\text { Know }\end{array}$ & & & & \\
\hline 1 & $\begin{array}{l}\text { Construction } \\
\text { works }\end{array}$ & 62.5 & 22.9 & 11.5 & 3.1 & 0 & $25.96 \%$ & 4.45 & 0.82 & 2 \\
\hline 2 & $\begin{array}{l}\text { Mechanical } \\
\text { works }\end{array}$ & 31.3 & 57.3 & 8.3 & 3.1 & 0 & $24.32 \%$ & 4.17 & 0.71 & 3 \\
\hline 3 & $\begin{array}{l}\text { Electrical } \\
\text { Works }\end{array}$ & 26 & 54.2 & 17.7 & 2.1 & 0 & $23.59 \%$ & 4.04 & 0.72 & 4 \\
\hline 4 & $\begin{array}{c}\text { Architectural } \\
\text { Works }\end{array}$ & 61.5 & 27.1 & 9.4 & 2.1 & 0 & $26.14 \%$ & 4.48 & 0.75 & 1 \\
\hline
\end{tabular}

\section{General construction works}

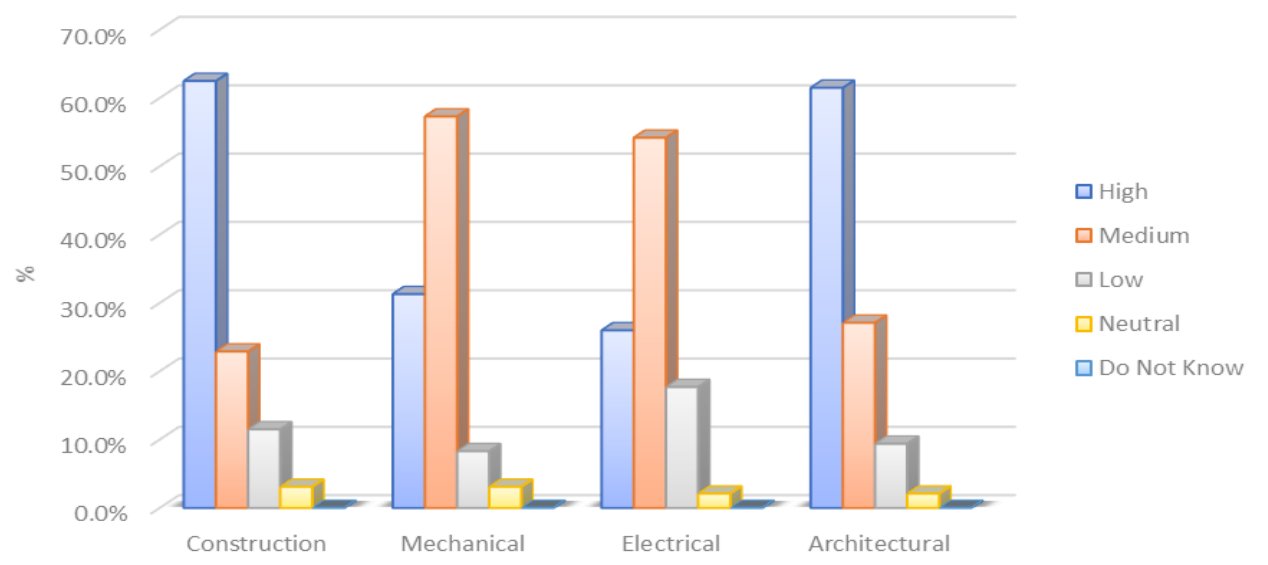

Figure.6. Range of impact for each type of general construction works on the cost of projects 


\section{IMPACT OF GENERAL TYPES OF WORKS}

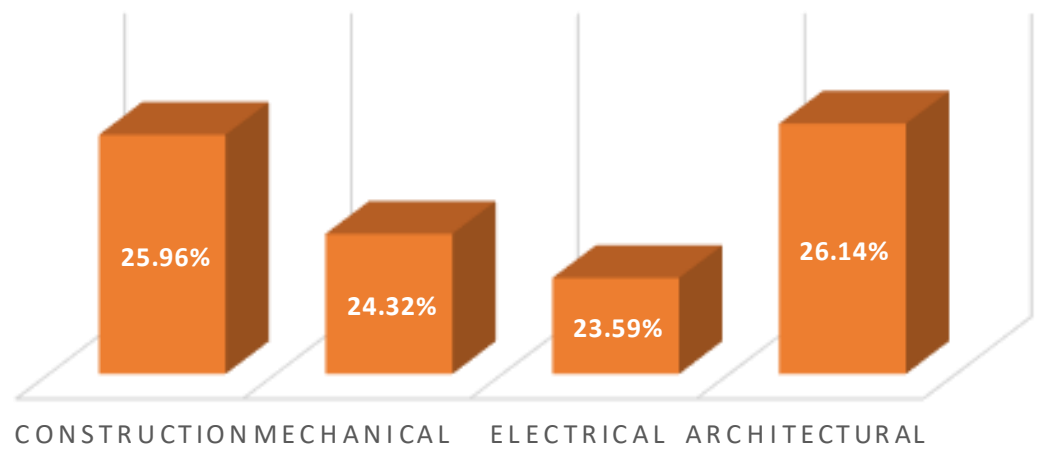

Figure.7. Percentage of impact of general types of construction works 1.1.1. Civil Underground works:

Table.5. Mean and standard deviation for civil underground works

\begin{tabular}{|c|c|c|c|c|c|c|c|c|c|c|}
\hline \multicolumn{11}{|c|}{ Civil Underground Works } \\
\hline \multirow[b]{2}{*}{ No } & \multirow[b]{2}{*}{ Factors } & \multicolumn{5}{|c|}{ Degree of effect $\%$} & \multirow[b]{2}{*}{ Percentage $\%$} & \multirow[b]{2}{*}{ Mean } & \multirow{2}{*}{$\begin{array}{l}\text { Standard } \\
\text { deviation }\end{array}$} & \multirow[b]{2}{*}{ Rank } \\
\hline & & High & Medium & Low & Neutral & $\begin{array}{l}\text { Do not } \\
\text { Know }\end{array}$ & & & & \\
\hline 1 & Design & 41.7 & 40.6 & 13.5 & 2.1 & 2.1 & $25.97 \%$ & 4.18 & 0.78 & 1 \\
\hline 2 & Earth works & 34.4 & 42.7 & 19.8 & 1 & 2.1 & $25.26 \%$ & 4.06 & 0.77 & 3 \\
\hline 3 & $\begin{array}{c}\text { Isolation } \\
\text { works }\end{array}$ & 18.8 & 45.8 & 30.2 & 3.1 & 2.1 & $23.38 \%$ & 3.76 & 0.79 & 4 \\
\hline 4 & Dewatering & 32.3 & 50 & 14.6 & 0 & 3.1 & $25.39 \%$ & 4.08 & 0.69 & 2 \\
\hline
\end{tabular}

\subsubsection{Civil skeleton works}

Table.6. Mean and standard deviation for civil skeleton works

\begin{tabular}{|c|c|c|c|c|c|c|c|c|c|c|}
\hline \multicolumn{11}{|c|}{ Civil skeleton works } \\
\hline \multirow[b]{2}{*}{ No } & \multirow[b]{2}{*}{ Factors } & \multicolumn{5}{|c|}{ Degree of effect $\%$} & \multirow[b]{2}{*}{ Percentage $\%$} & \multirow[b]{2}{*}{ Mean } & \multirow{2}{*}{$\begin{array}{l}\text { Standard } \\
\text { deviation }\end{array}$} & \multirow[b]{2}{*}{ Rank } \\
\hline & & High & Medium & Low & Neutral & $\begin{array}{l}\text { Do not } \\
\text { Know }\end{array}$ & & & & \\
\hline 1 & Design & 39.6 & 38.5 & 14.6 & 3.1 & 4.2 & $26.14 \%$ & 4.06 & 0.83 & 2 \\
\hline 2 & $\begin{array}{l}\text { Slabs } \\
\text { works }\end{array}$ & 34.4 & 49 & 11.5 & 1 & 4.2 & $26.27 \%$ & 4.08 & 0.72 & 1 \\
\hline 3 & $\begin{array}{c}\text { Columns } \\
\text { works }\end{array}$ & 20.8 & 44.8 & 27.1 & 3.1 & 4.2 & $24.13 \%$ & 3.75 & 0.82 & 3 \\
\hline
\end{tabular}




\begin{tabular}{lllllllllll}
\hline 4 & $\begin{array}{c}\text { Brick } \\
\text { works }\end{array}$ & 14.6 & 47.9 & 29.2 & 4.2 & 4.2 & $23.46 \%$ & 3.65 & 0.80 & 4 \\
\hline
\end{tabular}

\subsection{General mechanical works:}

Table.7. Mean and standard deviation for mechanical works

\begin{tabular}{|c|c|c|c|c|c|c|c|c|c|c|}
\hline \multicolumn{11}{|c|}{ Mechanical works } \\
\hline \multirow[b]{2}{*}{ No } & \multirow[b]{2}{*}{ Factors } & \multicolumn{5}{|c|}{ Degree of effect $\%$} & \multirow[b]{2}{*}{ Percentage $\%$} & \multirow[b]{2}{*}{ Mean } & \multirow{2}{*}{$\begin{array}{l}\text { Standard } \\
\text { deviation }\end{array}$} & \multirow[b]{2}{*}{ Rank } \\
\hline & & High & Medium & Low & Neutral & $\begin{array}{l}\text { Do not } \\
\text { Know }\end{array}$ & & & & \\
\hline 1 & HVAC & 50 & 33.3 & 7.3 & 0 & 9.4 & $35.31 \%$ & 4.15 & 0.74 & 1 \\
\hline 2 & Plumbing & 13.5 & 57.3 & 18.8 & 2.1 & 8.3 & $31.14 \%$ & 3.66 & 0.78 & 3 \\
\hline 3 & $\begin{array}{c}\text { Fire } \\
\text { Systems }\end{array}$ & 36.5 & 39.6 & 13.5 & 2.1 & 8.3 & $33.54 \%$ & 3.94 & 0.84 & 2 \\
\hline
\end{tabular}

\subsubsection{HVAC works:}

Table.8. Mean and standard deviation for HVAC Works

\begin{tabular}{|c|c|c|c|c|c|c|c|c|c|c|}
\hline \multicolumn{11}{|c|}{ HVAC Works } \\
\hline \multirow[b]{2}{*}{ No } & \multirow[b]{2}{*}{ Factors } & \multicolumn{5}{|c|}{ Degree of effect $\%$} & \multirow[b]{2}{*}{ Percentage $\%$} & \multirow[b]{2}{*}{6 Mean } & \multirow[b]{2}{*}{$\begin{array}{l}\text { Standard } \\
\text { deviation }\end{array}$} & \multirow[b]{2}{*}{ Rank } \\
\hline & & High & Medium & Low & Neutral & $\begin{array}{l}\text { Do not } \\
\text { Know }\end{array}$ & & & & \\
\hline 1 & Design & 35.5 & 45.8 & 10.4 & 1 & 7.3 & $33.95 \%$ & 4.01 & 0.76 & 2 \\
\hline 2 & $\begin{array}{c}\text { Air } \\
\text { condition }\end{array}$ & 38.5 & 37.5 & 17.7 & 0 & 6.3 & $33.99 \%$ & 4.02 & 0.79 & 1 \\
\hline 3 & Ventilation & 20.8 & 52.1 & 19.8 & 0 & 7.3 & $32.06 \%$ & 3.79 & 0.75 & 3 \\
\hline
\end{tabular}




\subsubsection{Plumbing works:}

Table.9. Mean and Standard deviation for plumbing works

\begin{tabular}{|c|c|c|c|c|c|c|c|c|c|c|}
\hline \multicolumn{11}{|c|}{ Plumbing Works } \\
\hline \multirow[b]{2}{*}{ No } & \multirow[b]{2}{*}{ Factors } & \multicolumn{5}{|c|}{ Degree of effect $\%$} & \multirow[b]{2}{*}{ Percentage $\%$} & \multirow[b]{2}{*}{ Mean } & \multirow[b]{2}{*}{$\begin{array}{l}\text { Standard } \\
\text { deviation }\end{array}$} & \multirow[b]{2}{*}{ Rank } \\
\hline & & High & Medium & Low & Neutral & $\begin{array}{l}\text { Do not } \\
\text { Know }\end{array}$ & & & & \\
\hline 1 & Design & 31.3 & 44.8 & 16.7 & 0 & 7.3 & $34.21 \%$ & 3.93 & 0.77 & 1 \\
\hline 2 & $\begin{array}{l}\text { Internal } \\
\text { Plumbing }\end{array}$ & 19.8 & 53.1 & 18.8 & 1 & 7.3 & $32.85 \%$ & 3.77 & 0.77 & 3 \\
\hline 3 & $\begin{array}{c}\text { External } \\
\text { Plumbing }\end{array}$ & 20.8 & 52.1 & 18.8 & 1 & 7.3 & $32.94 \%$ & 3.78 & 0.77 & 2 \\
\hline
\end{tabular}

\subsubsection{Fire system works:}

Table.10. Mean and standard deviation for fire system works

\begin{tabular}{|c|c|c|c|c|c|c|c|c|c|c|}
\hline \multicolumn{11}{|c|}{ Fire system Works } \\
\hline \multirow[b]{2}{*}{ No } & \multirow[b]{2}{*}{ Factors } & \multicolumn{5}{|c|}{ Degree of effect $\%$} & \multirow[b]{2}{*}{ Percentage $\%$} & \multirow[b]{2}{*}{ Mean } & \multirow[b]{2}{*}{$\begin{array}{l}\text { Standard } \\
\text { deviation }\end{array}$} & \multirow[b]{2}{*}{ Rank } \\
\hline & & High & Medium & Low & Neutral & $\begin{array}{l}\text { Do not } \\
\text { Know }\end{array}$ & & & & \\
\hline 1 & Design & 36.5 & 39.6 & 17.7 & 0 & 6.3 & $33.25 \%$ & 4.00 & 0.78 & 2 \\
\hline 2 & $\begin{array}{l}\text { Types of } \\
\text { Piping }\end{array}$ & 43.8 & 38.5 & 10.4 & 1 & 6.3 & $34.29 \%$ & 4.13 & 0.76 & 1 \\
\hline 3 & $\begin{array}{c}\text { Types of } \\
\text { Valves }\end{array}$ & 28.1 & 49 & 15.6 & 0 & 7.3 & $32.47 \%$ & 3.91 & 0.75 & 3 \\
\hline
\end{tabular}

\subsection{General electrical works:}

Table.11. Mean and standard deviation for general electrical works

\begin{tabular}{|c|c|c|c|c|c|c|c|c|c|c|}
\hline \multicolumn{11}{|c|}{ General Electrical Works } \\
\hline \multirow[b]{2}{*}{ No } & \multirow[b]{2}{*}{ Factors } & \multicolumn{5}{|c|}{ Degree of effect $\%$} & \multirow[b]{2}{*}{ Percentage $\%$} & \multirow[b]{2}{*}{ Mean } & \multirow{2}{*}{$\begin{array}{l}\text { Standard } \\
\text { deviation }\end{array}$} & \multirow[b]{2}{*}{ Rank } \\
\hline & & High & Medium & Low & Neutral & $\begin{array}{l}\text { Do not } \\
\text { Know }\end{array}$ & & & & \\
\hline 1 & $\begin{array}{l}\text { Low } \\
\text { current }\end{array}$ & 28.1 & 49 & 14.6 & 1 & 7.3 & $25.07 \%$ & 3.90 & 0.77 & 3 \\
\hline 2 & Power & 43.8 & 35.4 & 13.5 & 0 & 7.3 & $26.27 \%$ & 4.08 & 0.77 & 1 \\
\hline 3 & $\begin{array}{l}\text { Lighting } \\
\text { system }\end{array}$ & 19.8 & 41.7 & 30.2 & 1 & 7.3 & $23.53 \%$ & 3.66 & 0.84 & 4 \\
\hline 4 & $\begin{array}{l}\text { Fire alarm } \\
\text { system }\end{array}$ & 29.2 & 47.9 & 14.6 & 1 & 7.3 & $25.13 \%$ & 3.91 & 0.78 & 2 \\
\hline
\end{tabular}




\subsubsection{Low current works:}

Table 12.Mean and Standard deviation for low current works

\begin{tabular}{|c|c|c|c|c|c|c|c|c|c|}
\hline \multicolumn{10}{|c|}{ Low Current Works } \\
\hline \multirow[b]{2}{*}{ Factors } & \multicolumn{5}{|c|}{ Degree of effect $\%$} & \multirow[b]{2}{*}{ Percentage $\%$} & \multirow[b]{2}{*}{ Mean } & \multirow{2}{*}{$\begin{array}{l}\text { Standard } \\
\text { deviation }\end{array}$} & \multirow[b]{2}{*}{ Rank } \\
\hline & High & Medium & Low & Neutral & $\begin{array}{l}\text { Do not } \\
\text { Know }\end{array}$ & & & & \\
\hline 1 Design & 32.3 & 46.9 & 10.4 & 1 & 9.4 & $34.03 \%$ & 3.92 & 0.79 & 1 \\
\hline 2 CCTV & 21.9 & 46.9 & 19.8 & 1 & 10.4 & $32.04 \%$ & 3.69 & 0.86 & 3 \\
\hline $3 \quad$ BMS & 39.6 & 35.4 & 12.5 & 1 & 11.5 & $33.94 \%$ & 3.91 & 0.87 & 2 \\
\hline
\end{tabular}

1.3.2. Power supply works:

Table.13. Mean and standard deviation for power supply works

\begin{tabular}{|c|c|c|c|c|c|c|c|c|c|c|}
\hline \multicolumn{11}{|c|}{ Power Supply Works } \\
\hline \multirow[b]{2}{*}{ No } & \multirow[b]{2}{*}{ Factors } & \multicolumn{5}{|c|}{ Degree of effect $\%$} & \multirow[b]{2}{*}{ Percentage $\%$} & \multirow[b]{2}{*}{ Mean } & \multirow[b]{2}{*}{$\begin{array}{l}\text { Standard } \\
\text { deviation }\end{array}$} & \multirow[b]{2}{*}{ Rank } \\
\hline & & High & Medium & Low & Neutral & $\begin{array}{l}\text { Do not } \\
\text { Know }\end{array}$ & & & & \\
\hline 1 & Design & 31.3 & 41.7 & 19.8 & 0 & 7.3 & $32.92 \%$ & 3.90 & 0.80 & 3 \\
\hline 2 & Cables & 33.3 & 47.9 & 10.4 & 1 & 7.3 & $33.71 \%$ & 3.99 & 0.75 & 1 \\
\hline 3 & $\begin{array}{c}\text { Electric } \\
\text { panels }\end{array}$ & 31.3 & 51 & 6.3 & 4.2 & 7.3 & $33.36 \%$ & 3.95 & 0.81 & 2 \\
\hline
\end{tabular}

\subsubsection{Lighting system works:}

Table.14. Mean and standard deviation for lighting system works

\begin{tabular}{|c|c|c|c|c|c|c|c|c|c|c|}
\hline \multicolumn{11}{|c|}{ Lighting System Works } \\
\hline \multirow[b]{2}{*}{ No } & \multirow[b]{2}{*}{ Factors } & \multicolumn{5}{|c|}{ Degree of effect $\%$} & \multirow[b]{2}{*}{ Percentage $\%$} & \multirow[b]{2}{*}{ Mean } & \multirow{2}{*}{$\begin{array}{l}\text { Standard } \\
\text { deviation }\end{array}$} & \multirow[b]{2}{*}{ Rank } \\
\hline & & High & Medium & Low & Neutral & $\begin{array}{l}\text { Do not } \\
\text { Know }\end{array}$ & & & & \\
\hline 1 & Design & 31.3 & 47.9 & 11.5 & 2.1 & 7.3 & $49.93 \%$ & 3.94 & 0.79 & 2 \\
\hline 2 & $\begin{array}{l}\text { Types of } \\
\text { Lighting }\end{array}$ & 35.4 & 39.6 & 16.7 & 1 & 7.3 & $50.07 \%$ & 3.95 & 0.82 & 1 \\
\hline
\end{tabular}

\subsubsection{Fire alarm system works:}

Table.15. Mean and standard deviation for fire alarm system works 


\begin{tabular}{lccccccccccc}
\hline \multicolumn{10}{c}{ Fire Alarm System Works } \\
\hline \multirow{2}{*}{ No. } & Factors & \multicolumn{8}{c}{ Degree of effect \% } & \multicolumn{3}{c}{ High Medium Low Neutral } & $\begin{array}{c}\text { Do not Percentage\% Mean } \\
\text { Know }\end{array}$ & $\begin{array}{c}\text { Standard } \\
\text { deviation }\end{array}$ & Rank \\
\cline { 3 - 9 } 1 & Design & 34.4 & 40.6 & 16.7 & 0 & 8.3 & $33.47 \%$ & 3.93 & 0.80 & 2 \\
2 & Distribution & 27.1 & 47.9 & 15.6 & 0 & 9.4 & $32.67 \%$ & 3.83 & 0.79 & 3 \\
3 & $\begin{array}{c}\text { Types of } \\
\text { Sensors }\end{array}$ & 39.9 & 36.5 & 13.5 & 1 & 9.4 & $33.87 \%$ & 3.96 & 0.84 & 1 \\
\hline
\end{tabular}

\subsection{Exterior architectural works:}

Table.16. Mean and standard deviation for exterior architectural works

\begin{tabular}{|c|c|c|c|c|c|c|c|c|c|c|}
\hline \multicolumn{11}{|c|}{ Exterior Architectural Works } \\
\hline \multirow[b]{2}{*}{ No. } & \multirow[b]{2}{*}{ Factors } & \multicolumn{5}{|c|}{ Degree of effect $\%$} & \multirow[b]{2}{*}{ Percentage $\%$} & \multirow[b]{2}{*}{ Mean } & \multirow[b]{2}{*}{$\begin{array}{l}\text { Standard } \\
\text { deviation }\end{array}$} & \multirow[b]{2}{*}{ Rank } \\
\hline & & High & Medium & Low & Neutral & $\begin{array}{l}\text { Do not } \\
\text { Know }\end{array}$ & & & & \\
\hline 1 & $\begin{array}{l}\text { Facade's } \\
\text { material }\end{array}$ & 49 & 35.4 & 8.3 & 1 & 6.3 & $26.05 \%$ & 4.20 & 0.74 & 1 \\
\hline 2 & $\begin{array}{l}\text { Windows } \\
\text { material }\end{array}$ & 25 & 46.9 & 21.9 & 0 & 6.3 & $23.85 \%$ & 3.84 & 0.77 & 4 \\
\hline 3 & $\begin{array}{c}\text { Floor } \\
\text { material }\end{array}$ & 40.6 & 40.6 & 12.5 & 0 & 6.3 & $25.40 \%$ & 4.09 & 0.74 & 2 \\
\hline 4 & $\begin{array}{c}\text { Door's } \\
\text { material }\end{array}$ & 31.3 & 47.9 & 14.6 & 0 & 6.3 & $24.69 \%$ & 3.98 & 0.73 & 3 \\
\hline
\end{tabular}

\subsection{Interior architectural works:}

Table.17. Mean and standard deviation for Interior architectural works

\begin{tabular}{lllllllllll}
\hline \multicolumn{8}{c}{ Interior Architectural Works } \\
\hline \multirow{8}{*}{ No. } & Factors & \multicolumn{7}{c}{ Degree of effect \% } & \multicolumn{3}{c}{ High Medium Low Neutral } & $\begin{array}{c}\text { Do not } \\
\text { Know }\end{array}$ & Percentage\% Mean & $\begin{array}{c}\text { Standard } \\
\text { deviation }\end{array}$ & Rank \\
\cline { 2 - 10 } 1 & $\begin{array}{c}\text { Plaster } \\
\text { works }\end{array}$ & 17.7 & 39.6 & 34.4 & 1 & 7.3 & $23.23 \%$ & 3.59 & 0.85 & 4 \\
2 & Paint works & 24 & 41.7 & 27.1 & 0 & 7.3 & $24.24 \%$ & 3.75 & 0.82 & 3 \\
3 & $\begin{array}{c}\text { Isolation } \\
\text { works }\end{array}$ & 28.1 & 43.8 & 18.8 & 3.1 & 6.3 & $24.85 \%$ & 3.84 & 0.85 & 2 \\
4 & $\begin{array}{c}\text { Decoration } \\
\text { works }\end{array}$ & 55.2 & 30.2 & 8.3 & 0 & 6.3 & $27.68 \%$ & 4.28 & 0.70 & 1 \\
\hline
\end{tabular}


According to the data collected from the respondents, the Relative Importance Index (RII), (Khalid et al, 2015; Aibinu, 2006), can be used to measure the importance score for each category of work.

$R_{I I}=\frac{\sum_{i=1}^{5} w_{i} x_{i}}{A n}$

Where: ${ }^{w_{i}}$ : The weight given to the ${ }^{i^{\text {th }}}$ response ${ }^{(i=1,2,3,4,5)}, x_{i^{*}}$ The $\mathrm{i}^{\text {th }}$ response frequency, ${ }^{A}$ : The highest weight and ${ }^{n}$ Number of respondents. The type of works could classify according to their importance scores: ${ }^{R_{I I}}=(80-100)$ is Very High Importance, ${ }^{R_{I I}}=(60$ $79)$ is High Importance, $R_{I I}=(40-59)$ is Medium Importance, $R_{I I}=(20$ $39)$ is Low Importance and $R_{I I}=(0-19)$ is Very Low Importance. Table.18 shows the sub-works measured in this study in descending order according to the calculated importance score for each.

Table.18. Importance factor for each sub-works

\begin{tabular}{llll}
\hline Type of & Main Works & Sub- Works & RII \\
\hline Architectural & interior architecture works & Decoration works & $85.625 \%$ \\
Architectural & Exterior architecture works & Facade's material & $83.958 \%$ \\
Construction & underground const. works & Design & $83.542 \%$ \\
Mechanical & Fire system works & Types of Piping & $82.500 \%$ \\
Architectural & Exterior architecture works & Floor material & $81.875 \%$ \\
Construction & underground const. works & Dewatering & $81.667 \%$ \\
Construction & skeleton Const. works & Slabs works & $81.667 \%$ \\
Construction & underground const. works & Earth works & $81.250 \%$ \\
Construction & skeleton Const. works & Design & $81.250 \%$ \\
Mechanical & HVAC works & Air condition & $80.417 \%$ \\
Mechanical & HVAC works & Design & $80.229 \%$ \\
Mechanical & Fire system works & Design & $80.000 \%$ \\
Electricity & Power Supply works & Cables & $79.792 \%$ \\
Architectural & Exterior architecture works & Door's material & $79.583 \%$ \\
Electricity & Fire alarm system works & Types of Sensors & $79.232 \%$ \\
Electricity & Power Supply works & Electric panels & $78.958 \%$ \\
\hline
\end{tabular}




\begin{tabular}{llll}
\hline Type of & Main Works & Sub- Works & RII \\
General Works & Lighting system works & Types of Lighting & $78.958 \%$ \\
Electricity & Lighting system works & Design & $78.750 \%$ \\
Mectricity & plumbing works & Design & $78.542 \%$ \\
Electricity & Fire alarm system works & Design & $78.542 \%$ \\
Electricity & Low current works & Design & $78.333 \%$ \\
Mechanical & Fire system works & Types of Valves & $78.125 \%$ \\
Electricity & Low current works & BMS & $78.125 \%$ \\
Electricity & Power Supply works & Design & $77.917 \%$ \\
Architectural & Exterior architecture works & Windows material & $76.875 \%$ \\
Architectural & interior architecture works & Isolation works & $76.875 \%$ \\
Electricity & Fire alarm system works & Distribution & $76.667 \%$ \\
Mechanical & HVAC works & Ventilation & $75.833 \%$ \\
Mechanical & plumbing works & External Plumbing & $75.625 \%$ \\
Mechanical & plumbing works & Internal Plumbing & $75.417 \%$ \\
Construction & underground const. works & Isolation works & $75.208 \%$ \\
Construction & skeleton Const. works & Columns works & $75.000 \%$ \\
Architectural & interior architecture works & Paint works & $75.000 \%$ \\
Electricity & Low current works & CCTV & $73.750 \%$ \\
Construction & skeleton Const. works & Brick works & $72.917 \%$ \\
Architectural & interior architecture works & Plaster works & $71.875 \%$ \\
\hline
\end{tabular}

\section{Results and Discussion}

The deduced results after analyzing data from the questionnaire are illustrate the followings:

The results indicate that architectural works (with an impact percentage of $26.14 \%$ ) was the most effective type of works in the cost of projects compared with construction works $(25.96 \%)$, mechanical works (24.32\%) and electrical works (23.59\%) for general types of works. Where that, the design of the civil underground works has an impact percentage $25.97 \%$ surpassed the other civil underground works as dewatering (25.39\%), earth works (25.26\%), and isolation works $(23.38 \%)$. Moreover, the slabs work has the greatest impact factor, 
(26.27\%), on the cost for civil skeleton works (Design, columns works and brick works).

In the other hand, HVAC has the greatest impact percentage $35.51 \%$ compared of the two other main types, fire systems $(33.54 \%)$ and plumbing $(31.14 \%)$ of mechanical works. And going in details of the HVAC works, the results shows that the air condition works has a greater effect $(33.99 \%)$ than ventilation $(32.06 \%)$ and HVAC's design works (33.95). The design of plumbing works (34.21\%) is representing the most effective factor and more than the internal $(32.85 \%)$ and the external plumbing works $(32.94 \%)$. Investigating the influence of fire systems works, clears those types of piping (with impact percentage $34.29 \%$ ) is important, as a cost influence factor, more than types of valves $(32.47 \%)$ and design works of fire system $(33.25 \%)$. Further that, the power supply works has more impact (26.27\%) than low current works (25.07\%), lighting systems (23.53) and fire alarm systems works $(25.13 \%)$. And by studying the details of the power supply, the design of the cables works considered more effective $(33.71 \%)$ than its design $(32.92 \%)$ or electric panel works $(33.36 \%)$. The design of the low current works found to be more effective (with impact $34.03 \%$ ) than the CCTV works (32.04\%) or BMS works $(33.94 \%)$. And for the lighting system works, respondents almost agree that the types of lighting (50.07\%) and the lighting system design works $(49.93 \%)$ have nearly the same degree of effectiveness. Also, the types of sensors were the most effective (33.87\%) in fire alarm system works. In addition, the facades materials of the exterior architectural works have the greater impact $(26.05 \%)$ of the other works like floor materials $(25.04 \%)$, doors materials $(24.69 \%)$ and windows materials (23.85\%). Additionally, the decoration works of the interior architecture works has greater effect $(27.68 \%)$ than paint works $(24.24 \%)$, plaster works $(23.23 \%)$ and isolation work $(24.85 \%)$.

The previous analyzed results of the questionnaire clarified the difference in the impact ratio in project's cost of each type of alternative Works compared to other comparable and parallel types, but the difference is not large to represent a clear definitive result. Consequently, the questionnaire could represent an importance in the ordering of the different types of works as an influence factor in VE process for construction projects in Saudi Arabia. The deduced impact ratios and ranks could put the sub works for each main works. But 
putting in order all the sub works for all main works, with each other, in construction projects, requires using the Relative Importance Index $\left({ }^{R_{I I}}\right)$.

Accordingly, the importance score for each type of works have been calculated using the Relative Importance Index $\left({ }^{R_{I I}}\right)$, Table.18. Where that could clearly guide and help the VE stakeholders to organize and ordering their work to avoid wasting time in less impact types of work.

\section{Conclusion}

Value Engineering can be applied on any type of work for construction projects. This has an important impact and role in fostering conventional commodity value creativity, nurturing, and improving the core competitiveness of the business, and promoting sustainable economic and social growth at the national level. Value engineering, however, is no free work. It needs a monetary commitment by a multidisciplinary technical team for wages and fees, and an investment of time. The team effort seldom requires little portion of time to complete it with a suitable precision to accomplish its target. Furthermore, information gathering, certain elements of development, and report preparation may require more time. Value engineering team is not targeting to criticize designer's work. Their job is to extend the design process and choosing optimum materials for operation and maintenance cycles which builds upon and refines the accomplished work. A project administrator should reasonably expect the type of alternative Works that have the maximum return on investment for a VE study, and this will affect saving supposed time of VE process. The amount of savings and most effective type of alternative Works that can be expected to influence the results of VE process is difficult to predict.

So, this study concludes the most effective of alternative Works in construction sector, as an influence factor in value engineering process, which will help administrators and the VE team to accomplish applying VE process on effective alternative Works without losing time in less-effective types for that process.

This study contributed with presenting each sub works of the most effective alternative Works in a descending order, as influence factors 
in value engineering process in Saudi Arabia, from construction projects professional stakeholder's point of view. The results of the most effective types of alternative Works in construction projects are based on a questionnaire done on a sample of projects stakeholder's representing their point of view according to actual VE applications in constructions industry in Saudi Arabia with 95\% confidence level and margin error $10 \%$. It is sincerely hoped that this study would open new dimensions for improving the functionality of construction projects to finally provide the end user with the best facilities. The most outcomes of this paper can help for achieving, concentrating on, and acting on the most important types of works that are thought to influence the efficiency of value engineering. The findings will be useful in determining the most important steps to improve value engineering in the Saudi construction industry, and thus improve overall project completion time efficiency. The key contribution of this paper is to inform researchers and industry practitioners about how to use the $\mathrm{R}_{\mathrm{IIS}}$ for the types of works in this study as part of further research into the construction elements using any relevant techniques, such as value engineering (VE) and/or artificial neural network (ANN) techniques. Researchers and other practitioners may use outcome value indexes to measure the weights of influencing variables to obtain and predict relevant cost changes and rates using such techniques. The findings can also be used to model the interaction relationship between the main types of works influencing construction project budget cost to reduce construction costs in Saudi Arabia's construction division.

Table.19. List of Abbreviation

\begin{tabular}{ll}
\hline Abbreviation & Definition \\
\hline VE & Value Engineering \\
SAVE & Society of American Value Engineers \\
EPVA & affect engineering project value added \\
NLP & neuro-linguistic programming \\
VM & value management \\
OPS & overall project performance \\
EFA & exploratory factor analysis \\
SOE & support of excavation \\
LCC & life cycle cost \\
$n$ & Sample size \\
\hline
\end{tabular}




\begin{tabular}{ll}
\hline $\mathrm{E}$ & error margin \\
$\mathrm{N}$ & population size \\
$\mathrm{r}$ & the fraction of responses \\
$\mathrm{Z}$-score & the critical value for the level of confidence \\
$\mathrm{S}$ & standard deviations \\
$\bar{x}$ & Mean value \\
$\mathrm{RII}$ & the Relative Importance Index \\
$w_{\bar{i}}$ & The weight given to the $i^{\text {th }}$ response $(i=1,2,3,4,5)$ \\
$x_{\bar{i}}$ & The $i^{\text {th }}$ response frequency \\
$\mathrm{A}$ & The highest weight \\
\hline
\end{tabular}

\section{Declaration of Competing Interest}

This research did not receive any specific grant from funding agencies in the public, commercial, or not-for-profit sectors.

\section{References:}

[1] Chambers, R. (Ed.), (1988), "Managing Canal Irrigation: Practical Analysis from South Asia", Oxford Publishing, New Delhi, pp. 20:25.

[2] Ahmed K.; Idris O.; Ayodeji O.; Nicholas C.; and Mohanad B. (Vol. 147, Issue 4 (April 2021).). Impact of Value Management on Building Projects Success: Structural Equation Modeling Approach. Journal of Construction Engineering and Management, 2021.

[3] Aibinu, A. A. (2006). Construction delays and their causative factors in Nigeria. Journal of construction engineering and management, 132(7), 667-677.

[4] Al-Yousefi, A. (2012). Value Management (Concept \& techniques). Riyadh, Saudi Arabia: Twaig Publishing,5th ed.

[5] Al-Yousefi, A. S. (2007). Value engineering application benefits in sustainable construction. Riyadh: Project Management Institute Persian Gulf.

[6] Annappa, C. M., \& Panditrao, K. S. (2012). Application of value engineering for cost reduction-A case study of universal testing machine. International Journal of Advances in Engineering \& Technology, 4(1), 618.

[7] Assaf, S., Musallami, A. I. A., \& Sughaiyer, M. A. (1996). Value engineering in public construction projects in Saudi Arabia: Ways of expanding the use of value engineering in Saudi Arabia are explored after a detailed survey had been carried out. Building research and information, 24(3), 152-159.

[8] Dell'Isola, A. (1997). RS Means Value Engineering: Practical Applications for Design, Construction, Maintenance and Operations. Reed Construction Data.

[9] General Authority for Statistics in Saudi Arabia. (n.d.). General Authority for Statistics. Retrieved from General Authority for Statistics: https://www.stats.gov.sa/en . (Accessed, 2020).

[10] Ismail, A., Aminzadeh, R., Aram, A., \& Arshad, I. (2010). Value engineering application in highway projects. Am. J. Eng. Applied Sci, 3, 699-703. 
[11] J. Innes and F. Mitchell. (1990). "The Process of Change in Management: Some Field Study Evidence. Management Accounting Research, Vol. 1, No. 1pp. 3-19.

[12] Jae, L. (2018). Value Engineering for Defect Prevention on Building Façade. Journal of Construction Engineering and Management, Volume 144 Issue 8.

[13] Jingjun L.; Yan F.; Rongyan L.; and Wenle L. (August 24-25, 2020). An Algorithm for Optimizing the Location and Type Selection of Attached Tower Cranes Based on Value Engineering. International Conference on Construction and Real Estate Management. Stockholm, Sweden.

[14] Joel, W. (2017). "Value Engineering Evaluation Method for Sustainable Construction. AEI: Resilience of the Integrated Buildings, 1091 - 1102.

[15] Joel, W. (2018). Improving Creativity in the Value Engineering Process for Green Building Construction. Construction Research Congress 2018, April 2-4.

[16] Junying L.; Zhixiu W.; Martin S.; and Ling Y. (July 2019). How Contractor Behavior Affects Engineering Project Value-Added Performance. Journal of Management in Engineering, Vol. 35, Issue 4.

[17] Khalid Al-Gahtani, Ibrahim Al-Sulaihi, Raed Al Rashed, Ali Batarfi, (Novmber 2015). Key Performance Indicators for Value Management in Saudi Construction Industry. International Journal of Application or Innovation in Engineering \& Management (IJAIEM), Volume 4, Issue 11.

[18] Lindgreen, A., \& Wynstra, F. (2005). Value in business markets: What do we know? Where are we going?. . Industrial marketing management, 34(7), 732748.

[19] Mandelbaum, J. (2006). Value engineering handbook. Institute for Defense Analyses Alexandria vol. (no. ida-p-4114).

[20] Mohamed A.; Victoria B.; Ahmed A.; Grecia S. and Linda N. (2018). Value Engineering and Its Applications in Civil Engineering. Construction Research Congress 2018: Infrastructure and Facility Management.

[21] Raosoft, Inc. (n.d.). Database web survey software for gathering information. Retrieved from raosoft: http://www.raosoft.com/ (accessed, 2020)

[22] Sitotaw Y., Dimitrios I., David S., Andrew B.; and James M. (2018). (March 5-10, 2018). Combining Secant Piles with a Grouting Program Provides a Value Engineered Alternative for a Critical Support of Excavation. IFCEE 2018. Orlando, Florida.

[23] Society of American Value Engineering (SAVE), (n.d.). Society of American Value Engineering. Retrieved from Society of American Value Engineering: https://www.value-eng.org/. (Accessed, 2020).

[24] Taherdoost, H. (2017). Determining sample size; how to calculate survey sample size. International Journal of Economics and Management Systems, 2, pp237-239.

[25] Sharma, A., \& Belokar, R. M. (2012). Implementation of value engineering-A case study. International journal of marketing, financial services, and management research, 1(3). 


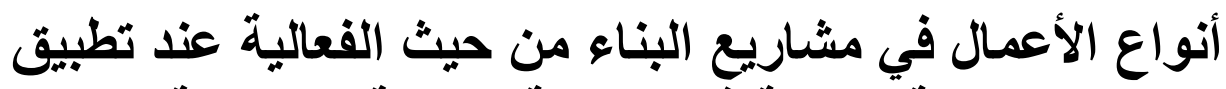

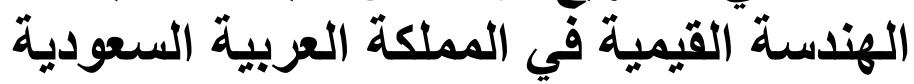

في مشاريع البناء، يعد تقليل التكلفة مع الحفاظ على مستوى الجودة أمرًا مهمًا، و الذي الذي التئي

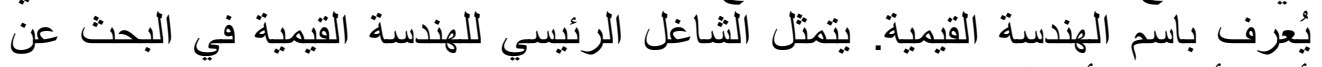

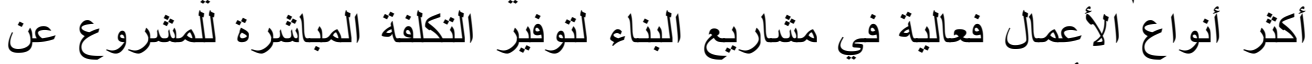

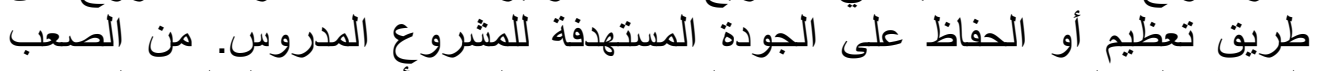

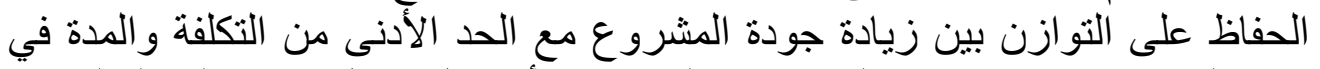

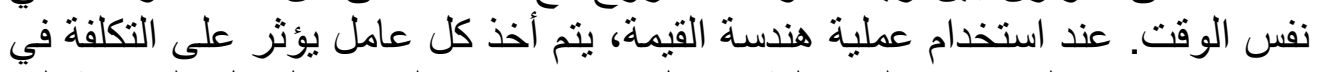

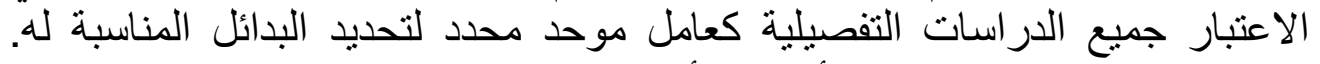

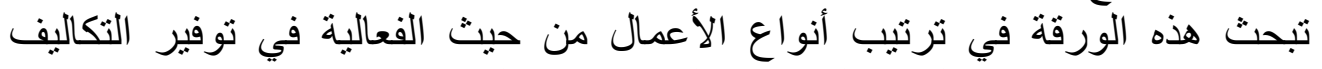

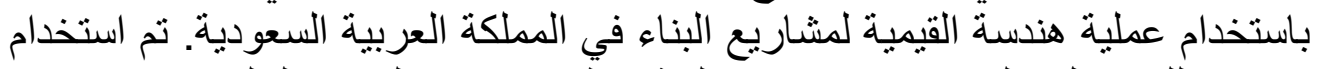

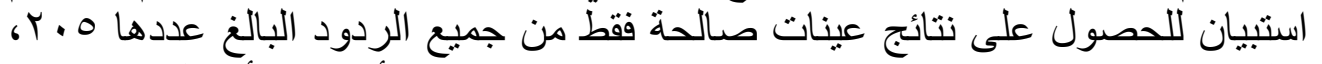

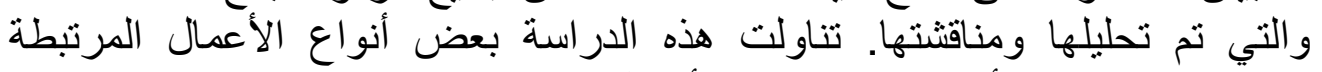

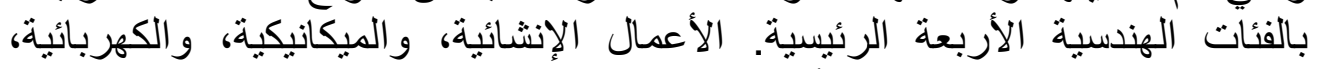

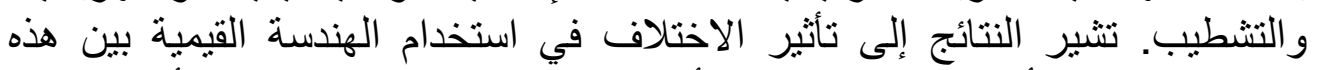

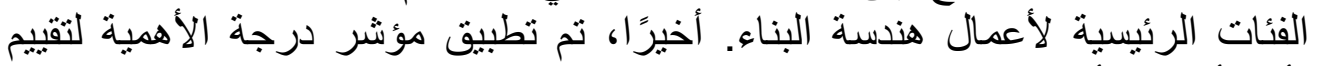

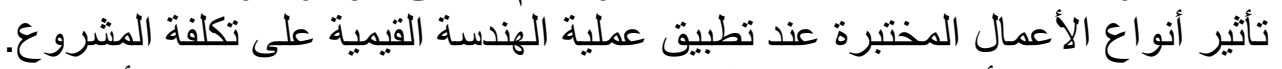

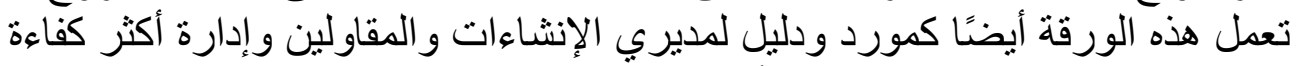

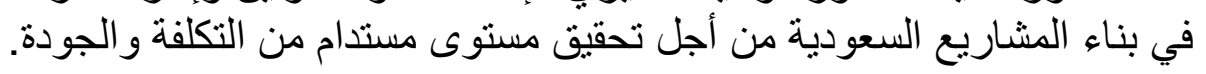

